\title{
In vitro studies on bactericidal activity and sensitivity pattern of isolated marine microalgae against selective human bacterial pathogens
}

K. P. Srinivasakumar and M. Rajashekhar

Department of Biosciences, Mangalore University, Mangala Gangothri, Karnataka- 574199, India srinibiotech@yahoo.co.in

Abstract: Ten microalgae cultured under controlled condition were tested for their antimicrobial activity against the selective bacterial pathogens in compliance with paper disk method. Five different solvents were used for the extraction. Isochrysis galbana showed overall inhibition of [16.22\%] followed by Chlorella marina [14.43\%], Nannochloropsis oculata [14.07\%], Dunaliella salina [13.91\%] and Pavlova lutheri [13.17\%]. These five microalgal strains were further investigated to examine concentration dependent microbicidal activity using tube dilution method. Microalgal strains were also investigated with agar-well diffusion method to understand the efficacy of antimicrobial principles against various bacterial pathogens. The findings in this study reveal that optimal activity is maintained by butanol extracts on Gram-positive bacteria; ethanol and petroleum ether extracts on both Gram-positive and Gram-negative bacteria; methanol extracts on Gram-negative organisms. Chloroform extracts, on the other hand did not show any significant antimicrobial activity. Keywords: Bactericidal, disk diffusion, microalgae, antibiotics, pathogens.

Introduction

A study by the World Health Organization (WHO) has shown that about $80 \%$ of the world's population still relies on traditional medicine (Farnsworth et al., 1985). Today, over $50 \%$ of the marketed drugs are either extracted from natural sources or produced synthetically using natural products as templates or starting materials. Marine environments host a wide range of bio-resources that have tremendous potential to provide new bio-products, including enzymes, antibiotics, anticancer agents, food additives, and pigments. The organisms yielding these bioactive compounds comprised a taxonomically diverse group of marine invertebrate animals, algae, fungi and bacteria (Mayer \& Gustafson, 2003). Many bioactive and pharmacologically active substances have been isolated from algae. For instance, extracts of marine algae were reported to exhibit antibacterial activity (Siddhanta et al., 1997). Marine organisms are known to contain a wide range of novel structures (Baker \& Murphy, 1981) and compounds with antimicrobial activity are increasingly being isolated from marine algae (Faulkner, 1986). The number of species so far examined is only a small percentage of the estimated total of 30,000 and it is likely that new antibiotics will be isolated. It is also evident from the earlier research that microalgae are significant resource for bioactive metabolites, particularly cytotoxic agents with applications in cancer chemotherapy (Moreau et al., 1988). Over 20 new drugs launched on the market between 2000 and 2005, originating from terrestrial plants, terrestrial microorganisms, marine organisms, and terrestrial vertebrates and invertebrates (Young et al., 2006). Many authors had found antibacterial activities of microalgae (Cooper et al., 1983; Findlay \& Patil, 1984; Viso et al., 1987; Kellam et al., 1988).

With the advent of Molecular biology, the screening of microalgae for antibiotics and active compounds has received considerable attention and a range of pharmacological properties have also been observed in the extracts of microalgae. Most of these bioactive compounds may find application in human or veterinary. However, the antimicrobial activity of microalgae has not adequately studied in India. In this context, the present paper illustrates the bactericidal activity of 10 marine microalgae against selected bacterial pathogens.

Material and methods

Sample collection

Algal samples were collected from sixty one sampling sites from Nerodi to S.P.Pattanam along the south east coast of Tamil Nadu, India with an average sampling distance of $5.42 \mathrm{kms}$. Marine water samples were collected using micro algal net cone shaped of mesh $20 \mu \mathrm{m}$ in size. The water samples were collected in the cup which was tied in the bottom of the algal net and was transferred to $0.1 \mathrm{~N} \mathrm{HCl}$ pretreated, steam sterilized screw cap bottles. The samples were preserved instantly into the ice bucket which was maintained at $5 \pm 1^{\circ} \mathrm{C}$ and transferred to the laboratory. Methods of isolation and maintenance of microalgae in axenic cultures are based on serial dilution culture techniques and agar plate method as described by (Gopinathan, 1996). Totally 10 microalgal species MA1: Isochrysis galbana, MA2: Nannochloropsis occulata, MA3: Dicrateria inornata, MA4: Chromulina freibergensis, MA5: Pavlova lutheri, MA6: Chlorella marina, MA7: Chaetoceros calcitrans, MA8: Dunaliella salina, MA9: Platymonas spp, MA10: Synechocystic salina was isolated from the sampling sites.

Culture of microalgae

Culture medium (Walne's medium), modified by (Laing, 1991) was taken in a series of test tubes and each inoculated with the isolated algal colonies in various concentrations. These tubes were kept under sufficient
Research article

CIndian Society for Education and Environment (iSee)
"Marine micro algae" http://www.indjst.org
Srinivasakumar \& Rajashekhar Indian J.Sci.Technol. 
light (1000 lux) and incubated in the algal culture room under room temperature $\left(22-28^{\circ} \mathrm{C}\right.$ ) with a $\mathrm{pH}$ of $8.2 \pm 1$. After 15 - 18 days, some discoloration was seen in the culture tubes due to the growth of microalgae. These were examined under the microscope and successful cultures were diluted and sub cultured in $20 \mathrm{ml}$ and subsequently to $250 \mathrm{ml}$; 1 litre Erlenmeyer flask and maintained as stock culture under a luminosity of 1000 lux. The cultured flasks were shaken thrice a day to ensure proper growth. The algae were further mass cultured in Haufkin's flask using Walne's medium and harvested in the exponential phase for experimental purpose.

\section{Separation of algal cells}

Microalgal cells in exponential growth phase were recovered from culture by batch centrifugation at $3000 \mathrm{rpm}$ for 10 minutes. The cells were repeatedly washed in normal saline $(0.85 \%$ sodium chloride) for three times by centrifugation at low speed. Microalgal samples were also extracted by ultrafiltration technique using KMS ultra-filtration tubular membrane of $0.1 \mu \mathrm{m}$ pore size. Extracted biomass were transferred to a pre-weighed dry filter paper using a clean spatula then placed in an oven at $60^{\circ} \mathrm{C}$ overnight to reach a fixed weight. The dry weight of the microalgal cells was weighed and the results were tabulated. Further microalgae were stored in refrigerator at $+4^{0} \mathrm{C}$ till extraction process.

\section{Preparation of algal extract}

Five different solvents were used in this experiment. They were Petroleum ether, Butanol, Ethanol, Methanol and Chloroform. By using these solvents algal cells were homogenized, extracted with respective solvents and filtered after extraction in accordance with (Khan et al., 1988). The extracts were dried under reduced pressure. All the extracts were preserved at $+4^{0} \mathrm{C}$ for further investigation.

\section{Collection of human bacterial pathogens}

The pathogens such as BP1- E. coli, BP2Klebsiella pneumoniae, BP3- Proteus vulgaris, BP4Pseudomonas aeruginosa, BP5- Pseudomonas fluorescens, BP6- Staphylococcus aureus, BP7Streptococcus pyogenes, BP8- Vibrio cholerae, BP9- Salmonella typhi and BP10- Bacillus subtilis were collected from a local clinical Laboratory. These bacteria's were cultured in L-broth medium (Bacto tryptone 1\%; yeast extract $0.5 \%$ and $\mathrm{NaCl}$ $0.5 \%)$.

Antibiotic sensitivity test with commercially available antibiotics (Kirby- Bauer method)

Agar Disk Diffusion method (Chabbert, 1963) was followed to perform the susceptibility test. The Muller-Hilton agar plates were prepared (Beef

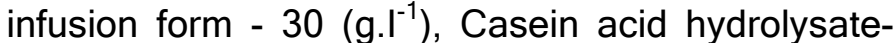

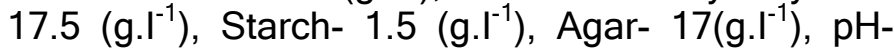
7.3). A swab of the test culture was taken aseptically and inoculated to the surface of the Muller-Hinton agar plate so as to make a lawn. This was allowed atleast 5 minutes for the agar surface to dry before applying disc. The forceps was sterilized by dipping in alcohol, then flamed and allowed to cool. The commercially available antibiotic disc was carefully taken and placed over the agar plate atleast $15 \mathrm{~mm}$ from the edge of the plate. The disc was pressed gently to give a better contact with agar. The plates were incubated for 16 to 18 hours at $37^{\circ} \mathrm{C}$. The zone of inhibition was observed around the antibiotics discs. The indication whether test organisms is resistant (no zone or inhibition) or sensitive (clear zone of inhibition) to the antibiotics was observed and tabulated.

\section{Screening of marine algal extracts against selective} bacterial pathogens (Agar disk diffusion method)

The human bacterial pathogens were subcultured in L-broth medium. About $15 \mathrm{ml}$ of sterile

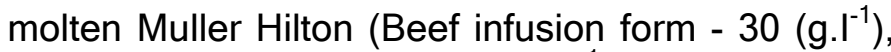
Casein acid hydrolysate- $17.5\left(\mathrm{~g} . \mathrm{I}^{-1}\right)$, Starch- 1.5 (g.l $\left.{ }^{1}\right)$, Agar- $17\left(\mathrm{~g}^{-1}\right)$, $\left.\mathrm{pH}-7.3\right)$ was introduced aseptically into sterile petridishes and after solidification; $12 \mathrm{hr}$ old L-broth culture of the test organisms were spread uniformly on the surface of the agar plates with the help of a sterile cotton swab (lawn culture). Then the empty sterile paper discs were dipped in the respective extracts and air dried in the room temperature and placed on the agar medium in petridishes, pre-spread with the bacterial pathogens using sterilized forceps. Then the plates were incubated at $37^{\circ} \mathrm{C}$ for $24 \mathrm{hrs}$. The antibacterial activity of the marine microalgal extract was observed through zone of inhibition around the disc. Then this zone of inhibition was measured in $\mathrm{mm}$ using a ruler and tabulated. Control discs soaked with the respective solvents were also run simultaneously.

\section{Concentration dependent bactericidal activity}

The tube dilution technique was performed to determine the minimal amount of microalgal active principles required to inhibit the growth of selective bacterial pathogens under laboratory conditions. In the present technique ten promising microalgal extracts from five microalgae MA1, MA2, MA5, MA6, and MA8 [2 extracts from each MA's], which shows optimal activity in the agar disk diffusion method were tested against respective bacterial pathogens. MA samples were added in an increasing
Research article

CIndian Society for Education and Environment (iSee)
"Marine micro algae" http://www.indjst.org
Srinivasakumar \& Rajashekhar Indian J.Sci.Technol. 
concentration of $20 \mu \mathrm{g}$ in a series of test tube of Muller Hinton broth freshly inoculated with one $\mathrm{ml}$ of corresponding bacterial pathogens $\left(1 \times 10^{5} \mathrm{cfu} / \mathrm{ml}\right)$. The experiment set up was incubated at $37^{\circ} \mathrm{C}$ for 24 hours. After incubation the culture samples were scanned at $620 \mathrm{~nm}$ and the results were recorded and tabulated.

Bacterial susceptibility testing using agar well diffusion method

The agar plate well-diffusion method was used as described by (Desta, 2005). Standardized inoculums from 12 hour old selective bacterial culture $\left(1-2 \times 10^{5} \mathrm{cfu} / \mathrm{ml}\right)$ were introduced onto the surface of sterile agar plate, and evenly distributed the inoculums by using a sterile glass spreader. Simultaneously $8 \mathrm{~mm}$ wells were cut from the plate using a sterile cork borer. $70 \mu \mathrm{l}$ of extract at a concentration of $10 \mathrm{mg} / \mathrm{ml}$ were introduced into each well. The agar plates were incubated aerobically at $37^{\circ} \mathrm{C}$ and the inhibition zones measured with a ruler and compared with the control well (well containing only the respective solvent) after $24 \mathrm{hr}$.

Table 1. Quantitative determination of dry weight of microalgae

\begin{tabular}{|c|c|c|c|c|c|c|}
\hline \multirow{3}{*}{$\begin{array}{l}\text { Microalgal } \\
\text { species } \\
\text { examined }\end{array}$} & \multicolumn{6}{|c|}{$\begin{array}{l}\text { Comparative determination of dry weight }[\mathrm{g} / \mathrm{L}] \text { of } \\
\text { microalgae extracted from } 1 \text { litre of exponential phase } \\
\text { culture using centrifugation / ultrafiltration method }\end{array}$} \\
\hline & \multicolumn{3}{|c|}{ Centrifugation } & \multicolumn{3}{|c|}{ Ultrafiltration } \\
\hline & $\begin{array}{c}\text { Day } \\
10\end{array}$ & Day 12 & Day 14 & Day 10 & Day 12 & Day 14 \\
\hline MA-1 & 2.166 & 2.666 & 2.867 & 2.237 & 2.873 & 3.017 \\
\hline MA-2 & 2.933 & 3.033 & 4.126 & 3.126 & 3.237 & 4.237 \\
\hline MA-3 & 3.356 & 3.343 & 3.363 & 3.849 & 3.627 & 3.787 \\
\hline MA-4 & 1.526 & 2.166 & 2.563 & 1.437 & 2.176 & 3.016 \\
\hline MA-5 & 3.266 & 3.279 & 3.126 & 3.473 & 3.337 & 3.231 \\
\hline MA-6 & 2.033 & 2.633 & 2.663 & 2.633 & 2.836 & 2.137 \\
\hline MA-7 & 1.216 & 1.543 & 1.769 & 1.267 & 1.332 & 1.679 \\
\hline MA-8 & 2.133 & 1.766 & 2.337 & 2.367 & 1.832 & 2.446 \\
\hline MA-9 & 0.866 & 0.986 & 1.436 & 0.976 & 0.996 & 1.332 \\
\hline MA-10 & 2.666 & 2.966 & 3.234 & 2.763 & 3.016 & 3.743 \\
\hline
\end{tabular}

Results and discussion

The dry weight of microalgal samples extracted from 1 litre of culture medium using centrifugation and ultrafiltration method was analyzed using paired sample statistical analysis (Table 1). The mean difference of micro algal samples extracted on day 10 by centrifugation method was $2.216 \pm 0.847 \&$ SEM of 0.267 , on day 12 was $2.438 \pm 0.794 \&$ SEM of 0.251 , on day 14 was $2.748 \pm 0.786 \&$ SEM of 0.248 and the yield of dry microalgae by ultrafiltration method on day 10 was $2.412 \pm 0.956$ \& SEM of 0.302 , on day 12 was 2.526 with a standard
Vol.2 No. 8 (Aug 2009)

ISSN: 0974- 6846 deviation of 0.894 \& SEM of 0.282 , on day 14 was 2.862 with a standard deviation of 0.951 \& SEM of 0.300 . It was also observed from the result of Pearson correlation method of all 3 paired samples shows significant correlations of C10:U10 0.981, C12:U12 0.993 and C14: U14 0.954 respectively. The result clearly indicates ultra-filtration as a preferable extraction procedure.

Ten bacterial pathogens were screened with different 16 commercially available discs. It was observed that Furazolidone shows maximum bacteriocidal activity across all selected bacterial pathogens with a mean value of $24.1 \pm 2.601$. Subsequently Nalidixic acid shows activity with a mean value of $19.9 \pm 2.806$ followed by Netilmycin which shows activity with a mean value of $19.1 \pm$ 1.911. Cephalexin, a first-generation cephalosporin antibiotic shows an overall activity of $18 \pm 3.464$. Amikacin and Ampicillin shows activity with a mean value of $16.5 \pm 3.689$ and $15.9 \pm 3.604$ respectively. Oxytetracycline shows activity with a mean value of $14.3 \pm 5.812$. Interestingly streptomycin shows activity towards $B$ substilus shows an inhibition zone of $9 \mathrm{~mm}$. The antibiotics like Vancomycin, Tetracycline, Kanamycin, Erythromycin, Gentamycin, Chloramphenicol, Amoxycillin and Cloxacillin were resistant towards the experimented bacterial strains.

The crude extract of 10 microalgal species were screened against ten bacterial pathogens and the results were illustrated in (Table 2). In the present study, microalgae were extracted with petroleum ether, methanol, ethanol, butanol and chloroform and tested against three gram positive and seven gram negative bacteria. Earlier researchers also used different solvents to determine the antibacterial activity of seaweed extracts such as methanol, toluene, diethyl ether, petroleum ether (Padmini et al., 1986), ethanol (Padmakumar \& Ayyakannu, 1986) and toluene: methanol mixture (Cassamese et al., 1981).

Petroleum ether [PE] extract was treated against ten bacterial pathogens and the result illustrates that Pavlova lutheri [MA5] shows total inhibitory zone of $36.8 \mathrm{~mm} \mathrm{26.41 \%}$ [3.68 \pm 4.4361] with maximum inhibition against Vibrio cholerae [BP8] 31.5\% and E. coli [BP1] 25.5\%. Platymonas sp [MA9] shows
Research article

CIndian Society for Education and Environment (iSee)
"Marine micro algae" http://www.indjst.org
Srinivasakumar \& Rajashekhar Indian J.Sci.Technol. 
Table 2. Sensitivity pattern of microalgal extracts against the bacterial pathogens

\begin{tabular}{|c|c|c|c|c|c|c|c|c|c|c|c|c|}
\hline \multirow{2}{*}{$\begin{array}{l}\text { Microalgae } \\
\text { used }\end{array}$} & \multirow[t]{2}{*}{ Solvent Used } & \multicolumn{10}{|c|}{ Bacterial pathogens used; Mean Inhibition zone in $\mathrm{mm}$} & \multirow{2}{*}{$\begin{array}{l}\text { Mean } \\
\text { Total }\end{array}$} \\
\hline & & BP1 & BP2 & BP3 & BP4 & BP5 & BP6 & BP7 & BP8 & BP9 & BP10 & \\
\hline \multirow{3}{*}{$\begin{array}{l}\text { Isochrysis } \\
\text { galbana }\end{array}$} & Butanol & 3.6 & NG & 5.3 & 7.3 & 3.2 & 13.3 & NG & 0 & 6.6 & 2.3 & 4.16 \\
\hline & Methanol & 0 & 2.6 & 2.6 & 6.3 & 3.2 & 0 & 0 & $\mathrm{NG}$ & 3.6 & 2.6 & 2.09 \\
\hline & chloroform & 0 & 0 & 0 & 0 & 4.2 & 0 & 4.6 & 0 & 1.6 & 0 & 1.04 \\
\hline \multirow{4}{*}{$\begin{array}{l}\text { Nannochlorop } \\
\text { sis oculata }\end{array}$} & Petroleum ether & 0 & 0 & 6.3 & 0 & 0 & $\mathrm{NG}$ & $\mathrm{NG}$ & 0 & 0 & 0 & 0.63 \\
\hline & Ethanol & 2.3 & 12.3 & 0 & 4.6 & 0 & 4.6 & 0 & 5.3 & 2.3 & 6.3 & 3.77 \\
\hline & Methanol & 0 & 0 & 0 & 0 & 0 & 2.3 & 0 & 0 & 0 & 0 & 0.23 \\
\hline & chloroform & 0 & 9.6 & 0 & 0 & 3.3 & 0 & NG & 3.3 & 0 & 4 & 2.02 \\
\hline \multirow{3}{*}{$\begin{array}{l}\text { Dicrateria } \\
\text { inornata }\end{array}$} & Petroleum ether & 0 & 8.6 & 3.3 & 2.6 & 0 & 0 & 0 & 4.6 & 0 & 0 & 1.91 \\
\hline & Butanol & 4.6 & 4 & 0 & 0 & 8.6 & $\overline{\mathrm{NG}}$ & 6.3 & 0 & 2.6 & 1.6 & 2.77 \\
\hline & Ethanol & 8.3 & 5.3 & 0 & 0 & 7.6 & 0 & 3.3 & 7.6 & 2.3 & 0 & 3.44 \\
\hline \multirow{3}{*}{$\begin{array}{l}\text { Chromulina } \\
\text { freibergensis }\end{array}$} & Ethanol & $\mathrm{NG}$ & 0 & 0 & $\mathrm{NG}$ & 6.3 & 0 & $\mathrm{NG}$ & 0 & 3.6 & 3 & 1.29 \\
\hline & Methanol & 0 & 2.3 & 0 & 0 & 1.6 & 0 & 0 & 0 & 0 & 0 & 0.39 \\
\hline & chloroform & 0 & 0 & 1 & 0 & 0 & 0 & 0 & 0 & 0 & 0 & 0.1 \\
\hline \multirow[b]{5}{*}{ Pavlova Iutheri } & Petroleum ether & 9.4 & 0 & 3.2 & 0 & 0 & 6.3 & 6.3 & 11.6 & 0 & 0 & 3.68 \\
\hline & Butanol & 0 & 0 & 8.6 & $\mathrm{NG}$ & 3.2 & 13.2 & 0 & 2.3 & 11.3 & 6.6 & 4.52 \\
\hline & Ethanol & 11.6 & 3.3 & 0 & NG & 0 & 3.6 & 0 & 0 & 0 & 2.6 & 2.11 \\
\hline & Methanol & 0 & 0 & 0 & 0 & 3.2 & 0 & 0 & 0 & NG & 0 & 0.32 \\
\hline & chloroform & 2.3 & 0 & 0 & 0 & 0 & 0 & 2.6 & 2.3 & 0 & 0 & 0.72 \\
\hline \multirow{3}{*}{$\begin{array}{c}\text { Chlorella } \\
\text { marina }\end{array}$} & Petroleum ether & 2.3 & 0 & 0 & 0 & 0 & 0 & 0 & 0 & 1.6 & 2.6 & 0.65 \\
\hline & Butanol & 0 & 9.3 & 11.6 & 8.6 & 7.3 & 0 & 0 & 8.6 & 0 & 0 & 4.54 \\
\hline & Ethanol & 0 & 0 & 0 & 7.6 & 13.3 & 0 & 0 & 6.3 & 3.6 & 0 & 3.08 \\
\hline \multirow{4}{*}{$\begin{array}{c}\text { Dunaliella } \\
\text { salina }\end{array}$} & Butanol & 0 & 0 & 0 & 6.6 & 0 & 0 & 12.6 & 11.3 & 6.6 & 0 & 3.71 \\
\hline & Ethanol & 0 & 0 & 0 & 0 & 3.6 & $\mathrm{NG}$ & 9.6 & 13.6 & 6.3 & 7.3 & 4.04 \\
\hline & Methanol & 0 & 0 & 0 & 0 & 3.3 & NG & 0 & 0 & 0 & 0 & 0.33 \\
\hline & chloroform & 0 & 2.6 & 5.6 & 0 & 0 & 0 & 11.3 & 2.3 & 0 & 0 & 2.18 \\
\hline \multirow{5}{*}{$\begin{array}{l}\text { Platymonas } \\
\text { sp. }\end{array}$} & petroleum ether & 0 & 6.6 & 3.6 & 0 & 0 & 9.6 & 9.6 & 2.3 & 0 & 0 & 3.17 \\
\hline & Butanol & 1.6 & 0 & 0 & 0 & 0 & 0 & 0 & 3.6 & 0 & 0 & 0.52 \\
\hline & Ethanol & 3.3 & 0 & 0 & $\mathrm{NG}$ & NG & 0 & 2.3 & 2.6 & 0 & 0 & 0.82 \\
\hline & Methanol & 2.3 & 0 & $\mathrm{NG}$ & 0 & 0 & 0 & 0 & 4.6 & 0 & 0 & 0.69 \\
\hline & chloroform & 0 & 0 & 0 & 0 & 0 & 0 & 0 & 0 & 0 & 0 & 0 \\
\hline \multirow{5}{*}{$\begin{array}{c}\text { Synechocystic } \\
\text { salina }\end{array}$} & petroleum ether & 0 & 0 & 0 & 0 & 0 & 0 & 0 & 0 & 0 & 0 & 0 \\
\hline & Butanol & 0 & 1.6 & 0 & 0 & NG & 2.3 & 0 & 0 & 0 & $\mathrm{NG}$ & 0.39 \\
\hline & Ethanol & 0 & 0 & 0 & $\mathrm{NG}$ & 0 & 3.6 & 0 & $\mathrm{NG}$ & 0 & 0 & 0.36 \\
\hline & Methanol & 4.3 & 0 & $\mathrm{NG}$ & 0 & 0 & 0 & 0 & 0 & 0 & 0 & 0.43 \\
\hline & chloroform & 0 & 0 & 0 & 0 & 0 & 0 & 0 & 0 & NG & 0 & 0 \\
\hline
\end{tabular}

BP- Bacterial Pathogens, NG- No Growth

total inhibitory zone of $31.7 \mathrm{~mm}, 22.75 \%$ [3.17 \pm pneumoniae [BP2] 20.8\%. I. galbana [MA1] had 4.0227] with maximum inhibition against gram shown maximum inhibition against $E$. coli[BP1] positive strains BP6, BP7 and Klebsiella 47.76\%. D. inornata [MA3] shows maximum inhibition against $K$. pneumoniae [BP2]. D. salina 
[MA8] shows inhibitory activity against Pseudomonas fluorescens. Interestingly no growth was observed in V. cholerae [BP8] Petri plates. $C$. marina [MA6], $N$. occulata [MA2], $C$. calcitrans [MA7], C. freibergensis [MA4] and S. salina [MA10] extracts has shown less impact over the selective bacterial pathogens and registers less inhibition zone. aureus [BP6] plate. C. freibergensis [MA4], Platymonas sp. [MA9] and Synechocystis salina [MA10] extracts had shown less bactericidal activity. Richard et al. (1988) showed B. subtilis as inhibited by the methanol extracts of Chlorella spp. This can be related to the present study where ethanol and butanol extracts of $C$. marina showed inhibitory activity against BP2, BP3, BP4, BP5, BP8, BP9

Table 3. Agar plate well diffusion method - mean bacterial susceptibility test with hole diameter subtracted

\begin{tabular}{|c|c|c|c|c|c|c|c|c|c|c|c|c|}
\hline \multirow{2}{*}{ Microalgae used } & \multirow{2}{*}{$\begin{array}{l}\text { Solvent } \\
\text { Used }\end{array}$} & \multicolumn{11}{|c|}{ Bacterial pathogens used } \\
\hline & & BP1 & BP2 & BP3 & BP4 & BP5 & BP6 & BP7 & BP8 & BP9 & BP10 & Total \\
\hline \multirow{2}{*}{$\begin{array}{l}\text { Isochrysis } \\
\text { galbana }\end{array}$} & Butanol & 6.6 & 10.6 & 6.6 & 9.6 & 4.3 & 14.6 & 12.3 & 0 & 5.6 & 2.6 & 7.28 \\
\hline & Ethanol & 14.3 & 0 & 13.3 & 2.6 & 0 & 6.3 & 0 & 8.6 & 11.3 & 9.6 & 6.6 \\
\hline \multirow{2}{*}{$\begin{array}{c}\text { Nannochloropsis } \\
\text { oculata }\end{array}$} & Butanol & 14.6 & 13.3 & 5.6 & 0 & 7.6 & 3.6 & 0 & 6.3 & 0 & 9.3 & 6.03 \\
\hline & Ethanol & 3.3 & 13.3 & 0 & 4.3 & 0 & 4.6 & 0 & 6.3 & 3.6 & 7.6 & 4.3 \\
\hline \multirow[b]{2}{*}{ Pavlova lutheri } & $\begin{array}{l}\text { petroleum } \\
\text { ether }\end{array}$ & 11.6 & 0 & 4.6 & 0 & 0 & 8.6 & 7.6 & 12.3 & 0 & 2.3 & 4.7 \\
\hline & Butanol & 0 & 0 & 7.6 & 11.3 & 6.3 & 14.6 & 0 & 3.6 & 10.6 & 8.1 & 6.21 \\
\hline \multirow[b]{2}{*}{ Chlorella marina } & Butanol & 0 & 10.6 & 11.3 & 8.3 & 7.6 & 0 & 3.6 & 7.3 & 0 & 0 & 4.87 \\
\hline & Methanol & 4.3 & 14.3 & 7.6 & 6.3 & 6.3 & 0 & 0 & 0 & 4.3 & 0 & 4.31 \\
\hline \multirow[b]{2}{*}{ Dunaliella salina } & Butanol & 7.6 & 0 & 0 & 7.3 & 0 & 10.3 & 11.6 & 4.6 & 3.6 & 0 & 4.5 \\
\hline & Ethanol & 3.3 & 6.3 & 0 & 0 & 5.6 & 3.6 & 11.3 & 5.6 & 8.3 & 7.6 & 5.16 \\
\hline
\end{tabular}

In the present study butanol extract showed maximum activity of $41.3 \%$ against the bacterial pathogens. Butanol [BT] extract of N. occulata [MA2] shares $18.1 \%$ of total inhibitory zone with better inhibitory against $E$. coli $24.3 \%, K$. pneumoniae [12.6 mm] and Bacillus subtilis $15.6 \%$. The results support earlier investigations by Kellar and Walker, (1989) where the extracts of $N$. maculata and $N$. oculata were inhibitory against Streptococcus faecalis and Bacillus subtilis. Chlorella marina [MA6] BT extract registered $15 \%$ of totalinhibitory activity against gram negative strains $P$. vulgaris $25.5 \%, K$. pneumoniae $20.4 \%$, $P$. aeruginosa \& $V$. cholerae $18.9 \%$ and $P$. fluorescens. BT extract of $P$. lutheri shows inhibitory against $S$. aureus $29.2 \%$ and $S$. typhi 25\%. No growth was identified in $P$. aeruginosa plate. I. galbana had shown activity against $S$. aureus $31.9 \%$ and $P$. aeruginosa $17.5 \%$. Remarkably no growth was identified in MA1 treated K. pneumoniae [BP2] and S. pyogenes [BP7] plates. $D$. salina inhibits $S$. pyogenes up to $33.9 \%$ and $V$. cholerae $30.4 \%$. No growth was observed in MA8 treated $S$. aureus plate. C. calcitrans inhibited gram positive strains $S$. pyogenes $34.8 \%$ and $S$. aureus $26.5 \%$. No growth was observed in $E$. coli [BP1] plate. $D$. inornata inhibits $P$. fluorescens growth up to $31 \%$. Additionally no growth was observed on $S$. strains.

The growth of gram negative bacterial pathogens $P$. vulgaris $26.9 \%$, E. coli $26.3 \%$ and $S$. typhi $22.6 \%$ were inhibited by the ethanol [ET] extract of I. galbana. MA1 also exhibit minimal activity against gram positive strains. Ethanol extract of $D$. salina shows $33.6 \%$ of inhibitory activity against $V$. cholerae [BP8] and $23.7 \%$ against $S$. pyogenes. No growth was identified on $S$. aureus [BP6] plate. $N$. occulata [MA2] shows inhibitory against $K$. pneumoniae $32.6 \%$ and shows minimal activity against $E$. coli, $P$. aeruginosa, $S$. aureus, $V$. cholerae, S. typhi and B. subtilis. D. inornata [MA3] shows inhibitory against $E$. coli $24.1 \%$ and $22 \%$ against $P$. fluorescens and Vibrio cholerae. ET extract of $C$. marina [MA6] shows inhibitory activity against $P$. fluorescens $43.1 \%, P$. aeruginosa $24.6 \%$ and $V$. cholerae $20.4 \%$ and $S$. typhi, B. subtilis. Earlier study by Miura et al. (1993) who tested crude extracts of ethanol - methanol from over 100 strains of marine microalgae against antimicrobial activity and found Bacillus subtilis as strongly inhibited by Chlorella sp. C. calcitrans [MA7] shows promising activity against $P$. aeruginosa up to 36\%, Vibrio cholerae $22.4 \%$ and $P$. fluorescens $21.4 \%$. Alternatively no growth was observed in $E$. coli plate. Visco et al. (1987) reported the activity of
Research article

(C)Indian Society for Education and Environment (iSee)
"Marine micro algae" http://www.indjst.org
Srinivasakumar \& Rajashekhar Indian J.Sci.Technol. 
Chaetoceros affinis against Aeromonas salmonicida, Pseudopiscida sp. and Alteromonas rubra; Chaetoceros brewis against Vibrio sp. and Aeromonas salmonicida, Chaetoceros danicus against $K$. pneumoniae, Proteus vulgaris, $P$. fluorescens, E. coli, S. typhi and $V$. cholerae. In the present study Chaetoceros calcitrans optimally inhibited the growth of BP1, BP4, BP6, BP7 and BP8. Pavlova lutheri [MA5] shows total inhibitory zone of $21.1 \mathrm{~mm}, 7.9 \%$ with an inhibitory against $E$. coli, K. pneumoniae [BP2], $S$. aureus [BP6] and $B$. subtilis [BP10]. No growth was observed in $P$. aeruginosa [BP4], plate. Ethanol extract of Chromulina freibergensis [MA4] Platymonas sp [MA9] and Synechocystis salina [MA10] extracts had shown less bactericidal activity. Earlier study conducted by Regini (2004) who screened Noctiluca scintillans against bacterial strains and found the ethanol extract showing antibacterial activity against Escherichia coli and acetone extract showing activity against $S$. faecalis. The study also showed variable response in ethanolic extracts by producing various zones of inhibition against different bacteria. Sastry and Rao (1994) showed antibacterial activity against gram positive and gram negative pathogenic strains after successive algal extraction with benzene, ethanol and methanol. This can be related to the present study where ethanol and butanol extracts resulted in various zones of inhibition against both gram positive and gram negative bacteria.

The results from methanol extract shows that except MA6 and MA1 all microalgal strains had shown less impact of total inhibitory zone $<7 \mathrm{~mm}$ against the bacterial pathogens. Methanol extract of Chlorella marina [MA6] registered maximum inhibitory activity against $K$. pneumoniae [BP2], $P$. vulgaris [BP3] and $P$. aeruginosa [BP4] and $P$. fluorescens [BP5] and $S$. typhi [BP9]. I. galbana [MA1] had shown inhibitory against $P$. aeruginosa [BP4], K. pneumoniae [BP2], Proteus vulgaris [BP3], $P$. fluorescens [BP5], S. typhi [BP9] and B. subtilis [BP10]. Remarkably no growth was identified in $V$. cholerae [BP8] plate. Earlier studies by (Richard et al., 1988), who screened the extracts of 100 cyanobacteria and 300 eukaryotic fresh petroleum ether algae and found antibacterial activity against $B$. subtilis and $S$. aureus and none against $E$. coli. Keller and Walker (1989) while screening the methanolic and hexane extracts of 132 marine microalgae, against six strains of bacteria, found that methanolic and hexane extracts were more effective against $\mathcal{S}$. aureus, $\mathcal{S}$. faecalis and less effective with regards to Bacillus subtilis. Chloroform [CF] extract of Dunaliella salina [MA8] registered inhibitory activity against $S$. pyogenes, $P$. vulgaris [BP3], K. pneumoniae and $V$. cholerae. Microalgae $N$. occulata had shown inhibitory against $K$. pneumoniae and no growth was identified on $S$. pyogenes [BP7] plate. No other MA extracts had shown promising activity against bacterial pathogens.

Pesando and Caram (1984) reported E. coli as more sensitive to macroalgae Laurencia obtuse. Issac and Hedge (1987) found $E$. coli as more sensitive to Sargassam johnstoni. In the present study $80 \%$ of screened microalgae had antimicrobial activity against $E$. coli. Padmini (1986) found $S$. typhi as more resistant to Sargassam johnstni. Padmakumar and Ayyakannu (1987) tested 80 species of macroalgae and only 19 species had antibacterial activity against $S$. typhi. In the present study the extracts of MA1, MA5, MA6, showed high antibacterial activity against $S$. typhi. Crude extracts of the microalgae showed activity only against gram negative bacteria as reported by Rao (1991). However, in the present study microalgal extracts showed activity against both gram positive and gram negative pathogens. Issac and Hedge (1987) found $P$. vulgaris as more sensitive to the marine algae $V$. pachyenma. In the present study Proteus vulgaris was found to be sensitive (9.8\%) to MA1, MA2, MA5, MA6, MA8. Among the 10 microalgae used against the bacterial pathogens, I. galbana showed highest inhibition [16.22\%] followed by $C$. marina [14.43\%], N. oculata [14.07\%], D. salina [13.91\%] and $P$. lutheri [13.17\%]. These five microalgal strains were further investigated in the present study to understand the concentration dependent bactericidal activity. Recently, Kim et al., 2001 studied hexane extract of $C$. elliposidea which inhibited the growth of $B$. subtilis and $S$. aureus: $T$. suecica showed relatively excellent antimicrobial activity against $E$. coli.

Concentration dependent bactericidal activity was performed in the present study and the obtained data were statistically analyzed by paired sample $t$ test to understand the efficacy of solvent extractions and antimicrobial properties. The bactericidal activity shown by butanol extract of MA1 against five bacterial pathogens BP1, BP3, BP4, BP6 \& BP9 were compared with the ethanol extract of MA1, which shown optimal activity against bacterial pathogens BP1, BP3, BP6, BP9 \& BP10.
Research article

CIndian Society for Education and Environment (iSee)
"Marine micro algae"
http://www.indjst.org
Srinivasakumar \& Rajashekhar Indian J.Sci.Technol. 
The result shows that butanol extract of $I$. galbana [MA1] shows respective bacterial clearance with a concentration of BP1 $(140 \mu \mathrm{g})$, BP3 $(140 \mu \mathrm{g})$, BP4 $(100 \mu \mathrm{g})$, BP6 $(80 \mu \mathrm{g}) \&$ BP9 $(120 \mu \mathrm{g})$, as ethanol extract of I. galbana [MA1] shows respective bacterial clearance with a concentration of BP1 $(80 \mu \mathrm{g})$, BP3 $(80 \mu \mathrm{g})$, BP6 $(160 \mu \mathrm{g})$, BP9 $(120 \mu \mathrm{g}) \&$ BP10 $(140 \mu \mathrm{g})$. Interestingly BP1 and BP3 were cleared by ethanol extract of MA1 at $80 \mu \mathrm{g}$ concentration when compared with butanol extract of MA1 $(140 \mu \mathrm{g})$, which is highly significant $[p<0.01]$. The bactericidal activity of MA2 butanol extract against five bacterial pathogens BP1, BP2, BP5, BP8 \& BP10 were compared with MA2 ethanol extract, which had shown optimal activity against bacterial pathogens BP2, BP4, BP6, BP8 \& BP10. The results elucidates that butanol extract of $N$. occulata [MA2] shows respective bacterial clearance with a concentration of BP1 $(80 \mu \mathrm{g})$, BP2 $(80 \mu \mathrm{g})$, BP5 $(160 \mu \mathrm{g})$, BP8 $(120 \mu \mathrm{g})$ \& BP10 $(100 \mu \mathrm{g})$, as ethanol extract of $N$. occulata [MA2] shows respective bacterial clearance with a concentration of BP2 $(80 \mu \mathrm{g})$, BP4 $(140 \mu \mathrm{g})$, BP6 $(140 \mu \mathrm{g})$, BP8 $(140 \mu \mathrm{g})$ \& BP10 $(120 \mu \mathrm{g})$. Interestingly BP2 was cleared by both butanol and ethanol extract of MA1 at $80 \mu \mathrm{g}$ concentration. MA5 petroleum ether extract was treated against five bacterial pathogens BP1, $\mathrm{BP} 3, \mathrm{BP} 6, \mathrm{BP} 7$ \& $\mathrm{BP} 8$ and the results were compared with MA5 butanol extract treated bacterial pathogens BP3, BP5, BP6, BP9 \& BP10. The results elucidates that $\mathrm{PE}$ extract of $P$. Iutheri [MA5] shows respective bacterial clearance with a concentration of BP1 $(120 \mu \mathrm{g})$, BP3 $(180 \mu \mathrm{g})$, BP6 $(160 \mu \mathrm{g})$, BP7 $(160 \mu \mathrm{g}) \&$ BP8 $(100 \mu \mathrm{g})$. The butanol extract of $P$. lutheri [MA5] shows respective bacterial clearance with a concentration of BP3 $(120 \mu \mathrm{g})$, BP5 $(160 \mu \mathrm{g})$, BP6 $(80 \mu \mathrm{g})$, BP9 $(100 \mu \mathrm{g})$ and BP10 $(120 \mu \mathrm{g})$. It was observed that a significant clearance of BP6 at $60 \mu \mathrm{g}[\mathrm{p}<0.001]$ and BP3 at $120 \mu \mathrm{g}$ $[p<0.005]$ by butanol extract of MA5.

Concentration dependent bactericidal activity of MA6 butanol and methanol extract against bacterial pathogens BP2, BP3, BP4, BP5, BP8 \& BP9 were analyzed. The results elucidates that butanol extract of C. marina [MA6] shows respective bacterial clearance with a concentration of BP2 $(100 \mu \mathrm{g})$, BP3 $(60 \mu \mathrm{g})$ [p<0.05], BP4 $(100 \mu \mathrm{g})$, BP5 $(140 \mu \mathrm{g}) \&$ BP8 $(120 \mu \mathrm{g})$, as methanol extract of $C$. marina [MA6] shows respective bacterial clearance with a concentration of BP2 $(80 \mu \mathrm{g})$, BP3 $(100 \mu \mathrm{g})$, BP4 $(100 \mu \mathrm{g})$, BP5 $(120 \mu \mathrm{g})$ and BP9 $(140 \mu \mathrm{g})$. The bacterial clearance of MA8 butanol extract against the bacterial pathogens BP4 $(120 \mu \mathrm{g})$, BP6 $(20 \mu \mathrm{g})$, BP7 $(60 \mu \mathrm{g}), \mathrm{BP} 8(80 \mu \mathrm{g})$ and BP9 $(120 \mu \mathrm{g})$ was compared with ethanol extract BP6 $(20 \mu \mathrm{g})$, BP7 $(80 \mu \mathrm{g})$, BP8 $(60 \mu \mathrm{g}), \quad$ BP9 $(120 \mu \mathrm{g})$ and BP10 $(100 \mu \mathrm{g})$. Walter and Mahesh (2000) screened 11 marine diatoms against 13 pathogenic bacteria and found the lipophilic and aqueous extracts of 6 diatoms showed high antibacterial activity. This is in conformity with the present study.

Comparative analysis of bactericidal activity between paper disk and well cut method for ten selective micro algal extracts against bacterial pathogens were also performed in the present study and the obtained data were statistically analyzed by paired sample t test (Table 3 ). It was observed that the crude butanol extract of I. galbana [MA1] had shown a total inhibitory measurement of $64.5 \mathrm{~mm}$, $13.35 \%$ in the paper disk method when and 72.8 $\mathrm{mm}, 13.50 \%$ in the well cut method ( $p<0.05$ ). Similarly the I. galbana [MA1] crude ethanol extract experiment in paper disk method had shown a total inhibitory measurement of $55.3 \mathrm{~mm}, 11.44 \%$ against $66 \mathrm{~mm}, 12.2 \%$ by well cut method $(p<0.05)$.

Crude butanol extract of $N$. occulata [MA2] shows total inhibitory activity of $60.3 \mathrm{~mm}, 11.1 \%$ in well cut method and $54.7 \mathrm{~mm} 11.3 \%$ in the paper disk method. Petroleum ether extract of $P$. lutheri [MA5] registered total inhibitory effect of $36.8 \mathrm{~mm}$, $7.61 \%$ in the paper disk method where well-cut method registered total inhibitory of $47.0 \mathrm{~mm}, 8.71 \%$ $(p<0.01)$. Methanol extract of $C$. marina [MA6] registered total inhibitory activity of $33.4 \mathrm{~mm}, 6.91 \%$ in the paper disk method: while a total inhibitory of $43.1 \mathrm{~mm}, 7.99 \%$ was registered in the well cut method. The well cut method of $D$. salina [MA8] shows total inhibitory of $45 \mathrm{~mm}, 8.34 \%$ on the crude butanol extract: while it shows total inhibitory of 55 $\mathrm{mm} 11.38 \%$ in the paper disk method. The results clearly indicated significant increment in microbicidal activity when performed using well-cut method.

References

1. Baker JT and Murphy V (1981) Compounds from Marine Organisms. CRC Press, Florida.

2. Caccamese S and Azzolina R (1979) Screening for antimicrobial activities in marine algae from Eastern Sicily. Planta med. 37, 333-339.

3. Caccamese S, Azzolina R, Furnari G, Furnari M, Cormaci M and Grasso S (1981) Antimicrobial and antiviral activities of some marine algae from eastern Sicily. Bot. Mar. 24, 367.

4. Chapman DJ (1980) Seaweeds and their uses. Chapman \& Hall, London.
Research article

CIndian Society for Education and Environment (iSee)
"Marine micro algae" http://www.indjst.org
Srinivasakumar \& Rajashekhar Indian J.Sci.Technol. 
5. Cooper S, Battat A, Marot $P$ and Sylvester $M$ (1983) Production of antibacterial activities by two bacillariophyceae grown in dialysis culture. Can. J. Microbiol. 29, 338-341.

6. Desta B (2005) Antimicrobial activity of 63 medicinal plants. J. Ethnopharmacol. 100, 168175.

7. Farnsworth NR, Akerele O, Bingel AS, Soejarto DD and Guo Z (1985) Medicinal plants in therapy. Bull. WHO. 63, 965-981.

8. Faulkner DJ (1986) Marine natural products. Natural Products Report. 3, 1-33.

9. Findlay JA and Patil AD (1984) Antibacterial constituents of the diatom Navicula delognei. J. Natural Products. 47, 815-818.

10. Gopinathan CP (1996) Life feed culturemicroalgae. Bull.Cent.Mar.Fish.Inst.48, 110-116.

11. Harder R (1917) Z. Botan. 9, 145-242.

12. Isacc SW and Hedge GR (1987) Freshwater algae of Karnataka state, Cartamman taxa from Uttara Kannada District: new flora of Kartae. Phykos. 26,123-129.

13. Kellam SJ, Cannell RJP, Owsianka AM and Walker JM (1988) Results of a large scale screening programme to detect antifungal activity from marine and freshwater microalgae in laboratory culture. British Phycol. J. 23, 45-47.

14. Kellar SJ and Walker JM (1989) Antibacterial activity from marine microalgae in laboratory culture. Br. Phycol. J. 24,191-194.

15. Khan NH, Rahman M and Kamal Nur-E (1988) Antibacterial activity of Euphorbia thymifolia Linn. Indian J. Med. Res. 87, 395-397.

16. Kim Se-Kwon, Jeon You-Jin, Kim Won-Suk, Back Ho-Cheol, Park Pyo-Jam, Byun Hee-Guk and Bai Sungchul C (2001) Biochemical Composition of Marine Microalgae and their potential Antimicrobial Activity. J. Fisheries Sci. \& Technol. 4 (2), 75.

17. Laing I (1991) Cultivation of marine unicellular algae. MAFF Laboratory Leaflet Number 67. Directorate of Fisheries Research Lowestoft, UK. pp: 31.

18. Mayer AMS and Gustafson KR (2003) Marine pharmocology in 2000: Antitumour and cytotoxic compounds. Intl. J. Cancer. 109, 291-299.

19. Miura $Y$, Sode $K$, Magasaki $Y$ and Matsunga $T$ (1993) Light induced antimicrobial activity of extracts from marine Chlorella. J. Mar. Biotechnol. 1, 143-146.

20. Moreau JD, Pasando P, Bernand P, Caram B and Pinnat JC (1988) Seasonal variation in the production antifungal substrates by some dictyotales (brown algae) from the French Mediterranean coast. Hydrobiologia. 2, 10971132.

21. Padmakumar K and Ayyakannu K (1986) Antimicrobial activity of some marine algae of Porto Novo and Pondichery waters, East coast of India. J. Mar. Sci. 13, 90-91.

22. Padmini SR, Rao PS and Karmarkar SM (1986) Antibacterial substances from brown algae, efficiency of solvents in the evaluation of antibacterial substances from Sargassum johnstonii. Bot. Mar. 29, 503-507.

23. Pesando D and Caram B (1984) Screening of marine algae from the French Mediterranean coast for antibacterial and antifungal activity. Bot. Mar. 27, 381-386.

24. Rao PS (1991) Biological investigation of marine algae screening of some green, red, brown seaweeds for their antimicrobial activity. Seaweed Res. Utiln. 14, 37-43.

25. Regini BGS (2004) Studies on the distribution and seasonal abundance of microflora in estuarine environment of Kanyakuamri district. Ph.D. Thesis, Manonmaninam Sundaranar Univ., Tirunelveli, Tamil Nadu, India. pp: 96-97.

26. Reichelt JL and Borowitzk MA (1984) Antimicrobial activity from marine algae: Results of a large scale screening program. Hydrobiologia. 116/117, 158-170.

27. Richard JP, Owsianka AM and Walker JM (1988) Results of large scale screening programme to detect antibacterial activity from freshwater algae. Br. Phycol. J. 2, 41-44.

28. Sastry VM and Rao GRK (1994) Antibacterial substances from marine algae: successive extraction using benzene, chloroform and methanol. Bot. Marina. 37, 357-360.

29. Siddhanta AK, Mody KH, Ramavat BK, Chauhan VD, Garg HS, Goel AK, Jinandra Doss M, Srivastava MN, Patnaik GK and Kamboj VP (1997) Bioactivity of marine organisms: Part VIIIScreening of some marine flora of Western coast of India. Indian J. Exp.Biol. 35, 638-643.

30. Visco AC, Pesando D and Baby C (1987) Antibacterial and antifungal properties of some marine diatoms in culture. Bot. Mar. 30, 41-45.

31. Young-Won Chin, Marcy J, Balunas, Hee Byung Chai and Douglas Kinghorn A (2006) Drug discovery from natural sources. The AAPS J. 8: (2), 28- 39. "Marine micro algae"
http://www.indjst.org
Srinivasakumar \& Rajashekhar Indian J.Sci.Technol. 